\title{
Mammalian research honoring the educational contributions of Grinnell Awardee Robert M. Timm
}

\author{
Robert P. Anderson,* Maria A. Eifler, Hayley C. Lanier, and Thorvald Holmes, Jr. \\ Department of Biology, City College of New York, City University of New York, New York, NY 10031, USA (RPA) \\ Program in Biology, Graduate Center, City University of New York, New York, NY 10016, USA (RPA) \\ Division of Vertebrate Zoology (Mammalogy), American Museum of Natural History, New York, NY 10024, USA (RPA) \\ University of Kansas Biodiversity Institute, 1345 Jayhawk Boulevard, Lawrence, KS 66045, USA (MAE) \\ Department of Biology, University of Oklahoma, Norman, OK 73072, USA (HCL) \\ Sam Noble Museum, University of Oklahoma, Norman, OK 73072, USA (HCL) \\ P.O. Box 1078, Willow Creek, CA 95573, USA (TH) \\ * Correspondent: randerson@ccny.cuny.edu
}

\begin{abstract}
This Special Feature honors Robert M. (Bob) Timm, who was recognized by the American Society of Mammalogists in 2017 with the Joseph Grinnell Award for his contributions to education in mammalogy. Bob has made great educational contributions through formal classroom and field instruction, interactions with researchers, public outreach, and mentorship of graduate students. Bob also has promoted equity and human diversity in mammalogy and joyfully assisted international colleagues (especially Latin Americans). In this Festschrift, many of his $\mathrm{Ph} . \mathrm{D}$. students offer the results of their recent mammalian research on topics as diverse as taxonomy and species identification, functional morphology, and biogeography and conservation on an environmentally dynamic planet.

Esta Sección Especial honra a Robert M. (Bob) Timm, quien fue reconocido por la American Society of Mammalogists en el 2017 con el Premio Joseph Grinnell, por sus aportes a la educación en la mastozoología. Bob ha realizado grandes contribuciones educativas dando clases en el aula y en el campo, interactuando con investigadores, involucrándose con el sector civil y asesorando a estudiantes de posgrado. Además, Bob ha promovido la igualdad y diversidad de participantes en la mastozoología, además de haber colaborado vehementemente junto a colegas internacionales (especialmente Latinoamericanos). En este homenaje, muchos de sus estudiantes de doctorado comparten los resultados recientes de sus investigaciones con mamíferos en temas tan diversos como la taxonomía e identificación de especies, la morfología funcional, y la biogeografía y conservación en un planeta medioambientalmente dinámico.
\end{abstract}

Key words: biogeography, conservation, Festschrift, human diversity, morphology, Nearctic, Neotropical, small mammals, species identification, taxonomy

The manuscripts of this Special Feature honor Robert M. Timm, recognized in 2017 by the American Society of Mammalogists (ASM) via the Joseph Grinnell Award for his outstanding contributions to education in mammalogy. Over the past four decades, Bob (as he is known to so many mammalogists) has contributed greatly to education in mammalogy through formal classroom and field instruction, interactions with researchers, public outreach, and mentorship of graduate students. This Special Feature constitutes a Festschrift emphasizing the results of the latter. In this frontispiece, we provide an overview of Bob's educational contributions to the field, note two cross-cutting activities, and then characterize the collection of contributed papers in the context of his research interests.

\section{Educational Contributions to Mammalogy}

As a faculty member at the University of Kansas, Bob's Mammalogy, Diversity of Life, and other courses (understandably biased toward mammals) reached myriad students. Additionally, he has regularly taught mammalogy portions of field courses with the Organization for Tropical Studies, impacting students from dozens of colleges and universities

(C) 2019 American Society of Mammalogists, www.mammalogy.org 
(Fig. 1). Despite his retirement in June 2017, Bob continues to teach undergraduates through independent study experiences designed to nurture their interests in field biology.

As a curator at the Field Museum of Natural History and later at the Biodiversity Institute and Natural History Museum at the University of Kansas, Bob has happily spent untold hours generously assisting visitors and imparting his vast knowledge of mammals, an effort that he continues today despite his formal retirement. He does the same at the annual ASM meetings, which he attends consistently. Through these interactions, Bob has had a strong, positive influence on countless students at various levels of their careers.

Bob passionately conveys information about mammals to the public. This comes in the form of public tours, informal lectures (for example, at field stations in Costa Rica), and formal products. Regarding the latter, Bob has produced the Mammals of Kansas webpage and field keys to bats (see York et al. 2019, through which he unknowingly participated in his own Festschrift). He also has provided support and guidance for museum displays, especially at the Natural History Museum at the University of Kansas, and contributed to public outreach via National Public Radio and interviews for magazine articles.

In total, Bob supervised or co-supervised 14 Ph.D. and master's students and a post-doctoral fellow at the University of Kansas. A testament to his mentorship, all of his Ph.D. students are employed in science. Additionally, his academic progeny have followed Bob's lead by training students themselves in a wide variety of formal and informal ways. In mentoring, Bob excels at promoting autonomy: as one co-nominator pointed out, Bob "knows when to allow students to work independently, to take their own risks, to make their own mistakes, and to meet their own successes."

Cutting across all four areas covered above, Bob also has promoted equity and human diversity in mammalogy. His past and ongoing mentorship includes concerted investments in the careers of female, minority, and

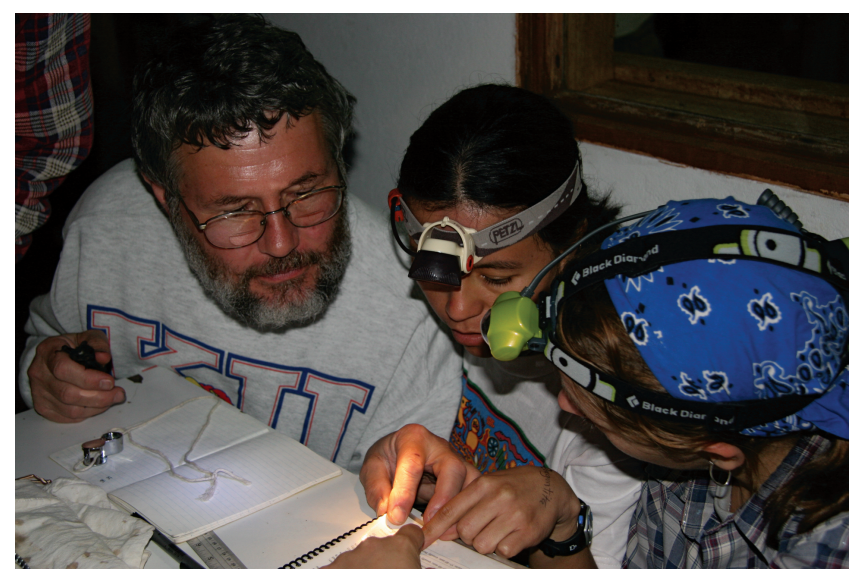

Fig. 1.-Grinnell Awardee Dr. Robert M. Timm facilitating hands-on education in mammalogy during a field course in Monteverde, Costa Rica in 2007 (photograph taken by Deedra McClearn). Timm's field teaching has dovetailed with his own research on bats and other small mammals, emphasizing their taxonomy, morphology, and natural history (see York et al. 2019). lesbian-gay-bisexual-transgender scientists, clearly making the point that everyone has equal potential and right to be a scientist. Additionally, he has joyfully assisted budding international colleagues, especially those from Latin America. One co-nominator wrote of Bob: "It doesn't matter if you are a well-known researcher or a curious undergraduate exploring research opportunities-he always takes as much time as needed to share his knowledge and experience, while treating everyone equally and as a colleague."

\section{Papers of this Special Feature}

In this Special Feature, many of Bob's Ph.D. students offer contributions illustrating two themes that have consistently run through his research: 1) small mammals, and 2) New World mammals, as well as the breadth of his knowledge and interests (Beasley and Maher 2019; Esselstyn et al. 2019; McCain 2019; Soley-Guardia et al. 2019; Vieira et al. 2019; Woodman and Wilken 2019; York et al. 2019). Although Bob's graduate students were and remain fiercely independent in their research (a quality he probably sought out, and certainly encouraged), this collection of manuscripts encapsulates his own interests remarkably well. First, all of the papers focus on or include small mammals. Second, with one exception, all of them entail studies of mammals of the New World, with the seeming outlier (Sulawesi) in many ways constituting an Old World counterpart to the diverse Costa Rican system in the Neotropics where Bob has worked for so many decades. Despite these two consistent themes, the individual papers represent a wealth of topics and approaches, spanning from taxonomy and species identification, to functional morphology, to biogeography and conservation on an environmentally dynamic planet. Along with parasites (not covered here, but indeed part of the research programs of several of his students), the additional key words biogeography, morphology, Nearctic, Neotropical, small mammals, species identification, and taxonomy perhaps better characterize Bob's research better than any others (Fig. 2). Despite strong individuality, Timm students were influenced markedly by Bob's interests, knowledge, and enthusiasm, as well as his strong connection to in-the-field natural history. Through both their consistency and variety, the manuscripts in this Special Feature celebrate the direct and indirect effects of Bob's efforts in graduate education in mammalogy; fittingly, many of them include collaborations with our own student-colleagues, continuing the educational philosophies that Bob inherited, modified, and passed on to us.

In our opinion, the ASM's Journal of Mammalogy constitutes the ideal venue for this Festschrift. Over many decades, Bob has furthered teaching and learning about mammals in copious ways through the ASM-via meeting attendance, editorial service, and a wide variety of leadership positions. In his literal and figurative booming voice, Bob has repeatedly reminded others of his priority by asking, "What is best for the students?" Fittingly, soon after receiving the Grinnell Award, he expressed that this recognition was the most meaningful to him because it came from his students and associates and 


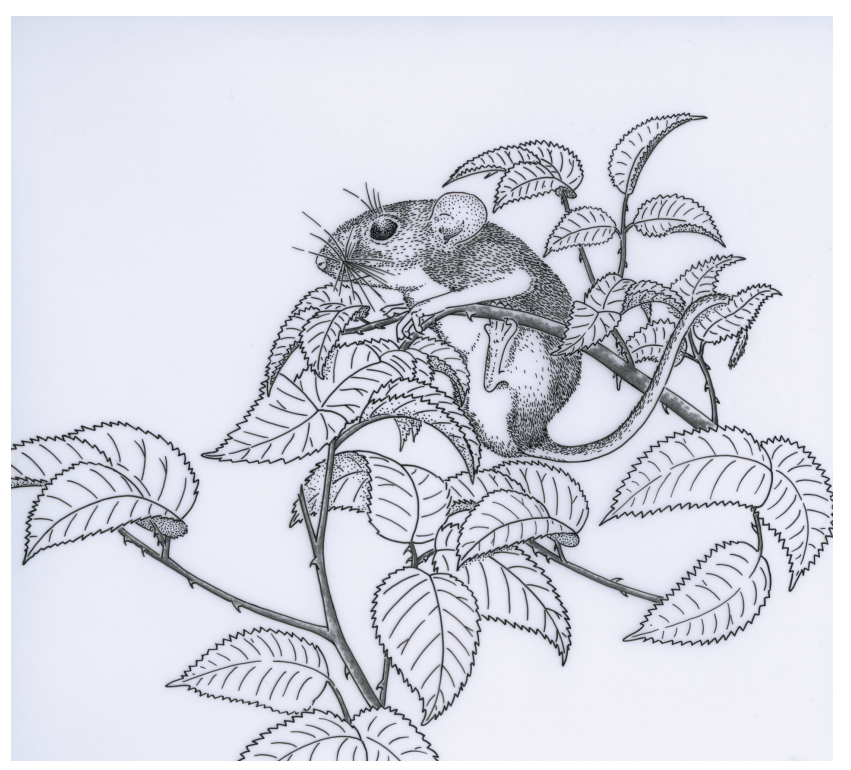

Fig. 2.-Peromyscus leucopus, one of many small mammals studied by Grinnell Awardee Dr. Robert M. Timm (e.g., Timm and Cook 1979) via a research approach linking natural history and morphology to conceptual issues in ecology and evolution. Illustration by Errol D. Hooper based on a photograph taken by Lawrence L. Master (Mammal Image Library \#073).

his "home society," the ASM. Together with other Timm students, we echo the Society's celebration of Bob's contributions to education in mammalogy and offer this frontispiece and the papers that follow as a tribute to him and an expression of gratitude for his investments in us.

\section{Literature Cited}

Beasley, E. M., ANd S. P. Maher. 2019. Small mammal community composition varies among Ozark glades. Journal of Mammalogy 100:1774-1782.

Esselstyn, J. A., A. S. Achmadi, H. Handika, T. C. Giarla, and K. C. Rowe. 2019. A new climbing shrew from Sulawesi highlights the tangled taxonomy of an endemic radiation. Journal of Mammalogy 100:1713-1725.

McCain, C. M. 2019. Assessing the risks to United States and Canadian mammals caused by climate change using a traitmediated model. Journal of Mammalogy 100:1808-1817.

Soley-Guardia, M., A. C. Carnaval, and R. P. Anderson. 2019. Sufficient versus optimal climatic stability during the Late Quaternary: using environmental quality to guide phylogeographic inferences in a Neotropical montane system. Journal of Mammalogy 100:1783-1807.

Timm, R. M., AND E. F. Cook. 1979. The effect of bot fly larvae on reproduction in white-footed mice, Peromyscus leucopus. American Midland Naturalist 101:211-217.

Vieira, M. V., D. Loretto, And B. PapI. 2019. Scaling of movements and body mass in a small opossum: evidence of an optimal body size in mammals. Journal of Mammalogy 100:1765-1337.

Woodman, N., And A. T. Wilken. 2019. Comparative functional skeletal morphology among three genera of shrews: implications for the evolution of locomotor behavior in the Soricinae (Eulipotyphla: Soricidae). Journal of Mammalogy 100:1750-1764.

York, H. A., B. Rodríguez-Herrera, R. K. LaVal, and R. M. Timm; ILLUSTRATED BY K. E. LindSAY. 2019. Field key to the bats of Costa Rica and Nicaragua. Journal of Mammalogy 100:1726-1749.

Special Feature Editor was Roger Powell. 